\title{
A framework for analyzing sex-selective abortion: the example of changing sex ratios in Southern Caucasus
}

This article was published in the following Dove Press journal:

International Journal of Women's Health

20 October 2014

Number of times this article has been viewed

\author{
Sophie A Hohmann' \\ Cécile A Lefèvre ${ }^{2,3}$ \\ Michel L Garenne ${ }^{4-6}$ \\ 'CNRS, CERCEC, Paris, France; \\ ${ }^{2}$ Université Paris Descartes, UMR \\ CEPED, PRES Sorbonne Paris Cité, \\ Paris, France; ${ }^{3}$ INED, Paris, France; \\ ${ }^{4}$ Institut Pasteur, Epidémiologie des \\ Maladies Emergentes, Paris, France; \\ IIRD, UMI Résiliences, Bondy, France; \\ ${ }^{6}$ Medical Research Council/Wits \\ Rural Public Health and Health \\ Transitions Research Unit (Agincourt), \\ School of Public Health, Faculty of \\ Health Sciences, University of the \\ Witwatersrand, Johannesburg, South \\ Africa
}

Video abstract

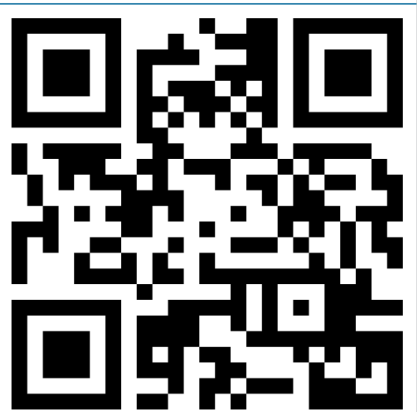

Point your SmartPhone at the code above. If you have a QR code reader the video abstract will appear. Or use: http://dvpr.es/lufr]Dw

Correspondence: Michel L Garenne Institut Pasteur, Epidémiologie des Maladies Emergentes, 25 rue du

Dr Roux, Paris, France

Tel +33 I 40613828

Email michel.garenne@pasteur.fr

\begin{abstract}
The paper proposes a socioeconomic framework of supply, demand, and regulation to explain the development of sex-selective abortion in several parts of the world. The framework is then applied to three countries of southern Caucasus (Armenia, Azerbaijan, and Georgia) where sex-selective abortion has developed since the collapse of the Soviet Union. The authors argue that sex-selective abortion cannot be explained simply by patriarchal social systems, sex discrimination, or son preference. The emphasis is put on the long-term acceptability of abortion in the region, on acceptability of sex-screening by both the medical establishment and by the population, on newly imported techniques of sex-screening, and on the changing demand for children associated with the major economic and social changes that followed the dismantlement of the Soviet Union.
\end{abstract}

Keywords: sex-selective abortion, sex-screening methods, value of children, demand for children, sex-preference, Southern Caucasus

\section{Introduction}

Sex-selective abortion (SSA), defined as the voluntary termination of pregnancy based on the anticipated sex of the child (most often a girl), has spread rapidly since the $1980 \mathrm{~s}$, due to the development of new sex-determination techniques in early pregnancy. SSA became highly prevalent in several parts of the world for a variety of reasons, and became a demographic phenomenon visible in the biased sex ratio at birth: by eliminating preferentially female fetuses, the sex-ratio at birth becomes abnormally high, and may reach values as high as 120 boys for 100 girls, or even more. This demographic signature makes it easy to trace SSA even in the absence of any statistics or detailed study of SSA. High prevalence of SSA is now found in parts of India, the People's Republic of China, South Korea, and Vietnam. More recently, SSA developed in countries of the Southern Caucasus, which at first glance seemed surprising to many observers. ${ }^{1-14}$

The rationale for SSA remains poorly understood. This paper challenges the common cultural framework of "patriarchal societies", "sex discrimination", and "preference for sons" in vogue in international organizations and in much of the literature on the topic. ${ }^{13,15}$ Indeed, most societies around the world are patriarchal but still a minority practice SSA. Preference for sons is almost universal in agricultural societies because of high demand for agricultural labor and inheritance systems, and in industrial societies, because of high demand for industrial labor, but only a minority of these societies accepted and practiced SSA. Preference for sons is less common in contemporary societies based on tertiary economics, due to high demand for women in the service 
industry and because of new social norms on equality of the sexes. However, many modern societies have not changed their traditional attitude towards a mild preference for sons. Even in advanced societies such as the US, there is still a mild preference for sons, visible in the higher probability of having a third child after two girls than after two boys. Son preference also has a cultural dimension, because of rationale or symbolic reasons: the need to transmit a patronym (patrilineal family name), the need to perform certain rites, or simply prestige. ${ }^{16-18}$

In this paper, we propose a broader socioeconomic framework of demand/supply/regulation to approach the problem in a systematic way and in a broader contemporary context. We will illustrate how the framework can be applied to the case of countries of Southern Caucasus. This work is primarily theoretical, but is also supplemented with qualitative field research. Since 2010, two of the authors ( $\mathrm{SH}$ and $\mathrm{CL}$ ) conducted field research in the three countries of Southern Caucasus, by interviewing physicians, gynecologists, lay persons, lawyers, and activists involved in women's rights.

\section{Framework}

The framework proposed for analyzing SSA behavior distinguishes several levels: on the supply side, the availability of sex screening and abortion techniques; on the demand side, a variety of factors; and with respect to regulation, various ethical and social norms and laws.

\section{Supply of sex-screening methods}

Sex-selection is not possible without efficient sexscreening methods. Several methods were developed in the past 50 years, which allow sex-determination in early pregnancy.

\section{Ultrasonography (obstetric sonography)}

Ultrasound screening machines became available in the 1970s. They provide a picture of the fetus, and are primarily used for detecting malformations of the fetus. The machine itself is costly, less so when produced in developing countries, but can be made rapidly profitable by multiplying the number of examinations, since the marginal cost of each additional exam is low. These machines are now widely available around the world, in public and private practices, including in low-income countries. The picture seen on the screen allows one to check for the sagittal sign as a marker of fetal sex. It can therefore be used for sex determination when genital organs are sufficiently developed; that is, around the
12 th week of pregnancy. Accuracy is estimated at about $86 \%$ when well-conducted with precise equipment, and increases with gestational age. ${ }^{19,20}$

\section{Amniocentesis (amniotic fluid test)}

and chorionic villus sampling

These are invasive methods based on sampling the amniotic sac or the placental tissue, and are potentially dangerous for the fetus. They are also mostly performed for detecting malformations of the fetus, and also permit sex determination. They are typically used at 11-15 weeks of pregnancy, earlier for chorionic villus sampling and later for the amniotic fluid test. Analysis of the samples requires an appropriate laboratory facility, and the whole process is rather costly. Precision of sex determination is assumed to be high. Amniocentesis was developed in the 1970s, and is now widely available in private and public hospitals throughout the world. Chorionic villus sampling has been available since the late 1980 s. $^{21}$

\section{DNA probe on maternal blood (cell-free fetal DNA)}

This technique requires only a blood sample from the mother and screens for a Y chromosome segment using polymerase chain reaction (PCR). It has been available since the early 2000s. The method is considered to be highly specific $(>98 \%)$. It can be used early in the pregnancy, as early as 7 weeks, although with low sensitivity (75\%). Sensitivity increases with duration of the pregnancy, and becomes optimal $(99 \%)$ at about 20 weeks. Similar tests can be performed using urine samples, but are considered unreliable because of low sensitivity. Blood tests are now widely available and accessible, even on the internet, for a relatively low cost. ${ }^{22}$

\section{Supply of abortion methods}

Several abortion methods have been developed over the years, many of them over the past 50 years. ${ }^{23-27}$

\section{Dilatation and curettage (D\&C)}

This is a surgical procedure, well-known in Western countries since the late 19th century, and widely available and used in the USSR since the 1920s. It was for a long time, until the 1960s, the only modern method of abortion. It consists of dilating the uterus before surgical removal of parts of the lining of the uterus and its content by scraping and scooping (curettage). If well-performed, the method is safe and efficient. However, numerous side effects and surgical errors have been reported. 


\section{Vacuum aspiration/Karman's method}

The vacuum aspiration method has been used since the 1970s. It requires some basic equipment and skills. Manual vacuum aspiration consists of removing the fetus or embryo, placenta, and membranes by suction using a manual syringe, while electric vacuum aspiration uses an electric pump. It has been widely used in Western countries since abortion became legal, and is considered safe and efficient up to 12 weeks of pregnancy. It may be used later in pregnancy after performing a special procedure of dilatation.

\section{Medical abortion (drug based)}

Medical abortion was developed in the 1970s and became available in the 1980s in Europe. It usually associates a synthetic prostaglandin (misoprostol) and an antiprogesterone (mifepristone) and is known as RU486. The dose of each drug depends on the duration of pregnancy. Misoprostol can be used alone, although with lower efficacy. When used properly, medical abortion is highly effective $(>98 \%)$ and safe, and considered not riskier than natural pregnancy. Medical abortion is a superior method for early termination of pregnancy ( $<9-11$ weeks of pregnancy), which in theory severely limits its use for SSA, since most sex-determination techniques are not sensitive at this duration; however, it can also be used later with increasing doses of the product, even at 12-24 weeks. ${ }^{26,27}$ Both drugs are registered in Armenia, Azerbaijan, and Georgia. Medical abortion with misoprostol (brand name: Cytotec) only is more and more used in countries of Southern Caucasus, and can be ordered on the Internet. However, when used alone and without proper medical support, it may have serious side effects.

\section{Injections}

Several injectable products have been used to terminate pregnancy. In Canada, methotrexate has been used with success in some $90 \%$ of cases. These injections seem rarely used elsewhere.

\section{Law, regulations, and social acceptability of induced abortion}

The USSR was a pioneer in legalizing induced abortion as early as 1921 , as a prime contraceptive method. ${ }^{28,29}$ In Europe, Sweden was also a pioneer, passing the first abortion law in 1938, followed by several amendments in 1946, 1963, and 1974. Several eastern countries (Japan, the People's Republic of China, most of Eastern Europe) legalized abortion shortly after World War II (1948-1955). They were followed in the 1960s and 1970s by many Western countries (countries in Western Europe, the US, Canada, and Australia), and a limited number of developing countries (including India), with a great variety of situations. Abortion is still restricted in some European countries (Poland, Ireland), in some states of the US, is sometimes legally restricted but widely practiced (as in New Zealand), or became legal only recently in others (as in Portugal). All countries where SSA occurs have legalized abortion for a long time, and are particularly tolerant to the several forms of abortion and of sex-detection. In contrast, many Western countries that allow induced abortion do not allow early sex-determination, in order to avoid SSA or because of the relative incompatibility between the timing of sex determination ( $>12$ weeks) and the optimal or legal timing for induced abortion ( $<12$ weeks). Some countries, however, allow for abortion beyond the 12th week, such as Sweden (18 weeks), India (20 weeks), The Netherlands (22 weeks), Japan, the UK, Vietnam (24 weeks), and the People's Republic of China (any duration), which opens more opportunities for SSA.

Social acceptability of SSA remains poorly documented, both at the level of the medical establishment and at population level. It is definitely extended in countries that allow it, and where it is widely practiced, but few studies are available on social acceptability in countries where it is not permitted. Recently, massive campaigns to ban SSA were launched by United Nations Agencies, in particular the United Nations Population Fund, and by the Council of Europe since 2011, but with limited success so far.

Some countries have passed laws conducive to SSA. The most obvious is the One-Child Policy in the People's Republic of China, which is conducive to strong selection since there is no option for a second child, and therefore for balanced offspring. In the context of patrilineal societies, where the name is transmitted in the patrilineage, not having a boy means the extinction of the patrilineage line. This attitude may change in the future with the relaxation of the One-Child Policy, and wider acceptability for two children in the People's Republic of China.

\section{Demand for sex-selective abortion}

The demand side for SSA is also complex and multifactorial, with several levels intertwined. We present below a number of arguments aiming at explaining emerging SSA behaviors.

\section{Perceived economic value of children}

Up until recently, the perceived economic value of boys and girls differed, as did their economic roles later in life. 
For centuries, parents invested more in boys than in girls because they expected more returns from the boys. This can be seen, for instance, in differential investments in education; until recently, male levels of education were higher than that of females. This has changed in Western societies in recent years, and is changing in most advanced societies of developing countries, including in Southern Africa. ${ }^{30}$ Differential attitudes of parents towards boys and girls also differ depending on their economic roles, in particular in agricultural and industrial societies. How these effects relate to SSA remains poorly documented and seems to be complex.

\section{Population pressure}

Strong population pressure has a number of effects, and in particular, on the status of women. In societies with heavy population pressure and low demand for additional births, such as India, the status of women tends to be low - women are often poorly treated, so that mothers do not want to have girls because they do not want them to suffer the same way they did. This argument is often given as a justification for SSA by women in face-to-face interviews. However, population pressure is not yet an issue in Southern Caucasus.

\section{Cost of children}

The differential cost of raising girls in certain societies is related to the previous issues. For instance, in India, the dowry system (money paid by the bride's family) implies a high cost for families with girls, whereas in many other societies, the bride price (paid by the groom's family) has the opposite incentive. In countries of Southern Caucasus, similar constraints seem to exist, although with a better balance between what the groom and the bride bring into the wedding. The contribution of the groom's family focuses on land, housing, jewelry and precious objects, and cash (the bride price), whereas the bride's family contributes in costly household equipment and linen. Of course, there are large differences between geographical areas, by socioeconomic status, or even between families. In addition, the fact that the girl leaves her family to live with her husband, often in her in-law's house, plays important psychological and economic roles.

\section{Economic recession and demand for children}

In case of severe economic recession, the demand for children tends to decline, and often in such cases, the total fertility rate declines. This happened during the 1929-1932 recession in the US, and could be seen also in Southern
Caucasian countries where fertility levels dropped to low levels after 1990.

\section{Migration strategies}

With the opening of borders, many families rely on the remittances from migrant workers, and this has been the case for a long time in southern republics of the former USSR, and particularly in Southern Caucasus. ${ }^{31,32}$ Remittances now account for a large share of the GDP, estimated at $18.5 \%$ in Armenia, 9.3\% in Azerbaijan, and 20.2\% in Georgia. ${ }^{33}$ Migrant workers are still mostly men, which is a further incentive for families to have more boys. However, this may change in the future, since young women now also migrate and remit to their families of origin. This is already the case in Georgia, where about half of migrant workers are women. ${ }^{34,35}$

\section{Family size and family composition}

Beyond the case of the one-child family in the People's Republic of China, the distribution of the number of children may also have an impact on the demand for SSA, and in particular, the frequency of odd and even numbers of children. For instance, in most Western societies where the modal value is two children per family, the preference, if any, seems to be for a balanced ratio of one boy and one girl. In transitional societies, where the most frequent desired family size is three children, as in India in recent years, there is a preference for two boys and one girl. A recent review of preferences expressed by women in Demographic and Health Surveys (DHS) showed an overwhelming preference for balanced numbers of boys and girls, a more frequent preference for more boys than for more girls, but also a number of situations where parents prefer more girls than more boys in selected countries of Latin America, Southern Africa, and Eastern Europe. In this study, Southern Caucasus countries did not show a preference for more boys or more girls differently from the average of the other countries investigated, nor from nearby countries not practicing SSA. ${ }^{36}$

\section{Prestige, novelty, and fashion}

In many traditional societies, for a variety of reasons linked to economic values, more prestige is associated with a male birth than with a female birth, so that the ideology tends to favor selection for boys. With the arrival of new sex-determination techniques in Southern Caucasus, SSA quickly became acceptable, was viewed positively as a new opportunity, and might even have become fashionable in some circles, adding to the other incentives. 


\section{Patronymic transmission}

In patrilineal societies, the legitimate child gets his father's name. This is a common reason given for justifying the preference for son, but this applies to most societies around the world.

\section{Inheritance rules}

In agrarian societies, having a son is important because social reproduction is based on inheriting the family farm and pursuing the farming activity. This sometimes leads to primogeniture (only the first male inherits the land), or to different rights between boys and girls. For instance, in Muslim countries, girls inherit only half their brother's share. All these factors may play a role in the wish of having a son. In Soviet countries, boys and girls were by law equally treated in terms of inheritance and this is still the case nowadays in the Caucasus. However, in the case of traditional Caucasian households, the second son - if any - is the one who is the most likely to stay in the family farm and pursue the activity, which is an incentive for having at least two boys.

\section{The case of Southern Caucasus}

In the three countries of Southern Caucasus, the sex-ratio at birth jumped from an average value of about 106 boys for 100 girls before 1990 to much higher values: 120 in Armenia in 2000, 118 in Azerbaijan in 2003, and 119 in Georgia in 1999, with some local variations. ${ }^{37}$ However, it should be noted that after a period of fast increase (1991-2000), the sex ratio at birth tended to stabilize in Azerbaijan, and even to decline in Armenia and Georgia (Figure 1). There is no doubt that these rapid and sudden changes were due to massive use of SSA. Further evidence is provided by DHS, which also show a marked increase in the sex-ratio at birth for deliveries that occurred after 1990, and a decline or stabilization in recent years. The increase in sex-ratios was mostly due to SSA at high-birth order, in particular after two or three girls in the family, a situation similar to that of India. In contrast, no such increase occurred in nearby areas, such as countries from the former USSR (Ukraine and Russia), Central Asian countries (Kazakhstan, Kyrgyzstan, Tajikistan, Turkmenistan, and Uzbekistan), and Middle Eastern countries (Turkey and Jordan). ${ }^{8,11,38}$

With respect to the supply side, there is ample evidence that both sex-screening and abortion techniques were widely available in the three countries, and were legal, relatively cheap, and affordable by most families. Abortion was the most common method of contraception until 1990, as in other countries of the former USSR. ${ }^{29,39}$ These three countries of Southern Caucasus had very high abortion rates even before 1990, Georgia being considered one of the world records (ratio of 1.1 abortions per live birth in the 1970s). According to a comparative study in 12 countries, Armenia, Azerbaijan, and Georgia had the highest abortion rates in the region, and higher than any other country from the former USSR. ${ }^{40}$ The same author noted that abortion rates were increasing in the 1990s in the three countries despite increasing modern contraception, whereas the opposite occurred in the other countries investigated. This could be due in part to SSA, although the study did not address this issue. In Southern Caucasus, abortion is affordable for most families at an average cost of about $€ 30-40$, and often free in public clinics.

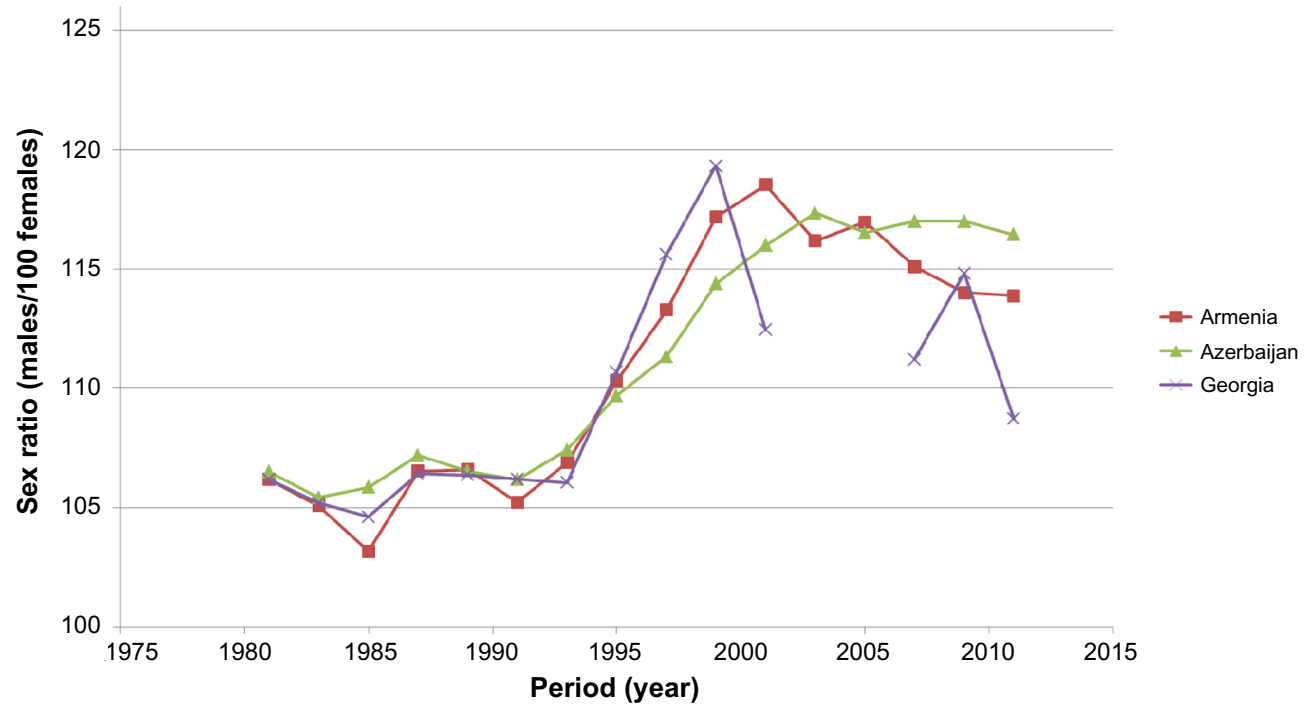

Figure I Trends in sex-ratio at birth in countries of the Southern Caucasus. 
Abortion pills are now also widely available and affordable, often under generic names: misoprostol is widely available at a low price (about $€ 20$ ), but mifepristone could be more expensive, with large differences in prices between countries and between providers.

Sex-screening methods became quickly available after the collapse of the Soviet Union, probably because of the efficient marketing of Western European manufacturing companies and the widespread acceptability from the medical establishment and from the government. Several methods of sex-determination became available in Southern Caucasus, although with different costs, targeting different segments of the population. Ultrasonography seems to have been the choice method in the 1990s, and is available at a low price (about $€ 30$ ), unless it requires a long travel to a city. In recent years, more and more women have used blood and urine tests. Blood and urine tests have been formally prohibited in Azerbaijan since 2008, but are still used because they became available through the Internet at a medium price (about €60).

Both the medical establishment and the population remained very tolerant to late abortion (in the second trimester) and to sex-determination. However, at the same time, they remained reluctant to discuss it publicly, since the matter is considered to be above all private. In terms of regulation, laws were very permissive up until recently. However, there are currently discussions about SSA in the media, because of pressure made by international organizations and by the European Council, who have different views and try to promote laws against SSA. Different arguments have been given to discuss the content and the pertinence of new legislation. Firstly, the choice belongs to the family, and the state should not interfere. Secondly, and more important, more radical interference from the state could induce more corruption and potentially less safe abortion conditions. Thirdly, banning SSA may slowly lead to banning all abortions. The situation and the relative importance given to these arguments differ by country and have evolved over time. There have even been recent discussions to ban abortion in Azerbaijan, following the example of Turkey, which seems to be going along the same lines. Likewise, under pressure from the Orthodox Church, Georgia has recently limited indications for abortions in the second trimester to serious medical or social conditions.

On the demand side, large social and economic changes occurred after the dismantling of the USSR. Above all, the economic recession, the dismantling of the social welfare system, the reform of the public health system, and the rising cost of living due to liberalization changed attitudes towards family size. As a result, the three Southern Caucasus countries underwent a serious drop in fertility after 1990, reaching total fertility rates as low as 1.6 children per woman in Georgia (2002-2005), 1.8 in Azerbaijan (2001), and 1.8 in Armenia (2001). The three countries underwent a serious economic recession with a sharp drop in income per capita after 1990. Consequently, these countries sent large numbers of migrant workers, mostly men, to Western Russia and Siberia, which increased the perceived economic value of boys. ${ }^{31,32}$ By year 2000, some 650,000 Azeri were working in Russia out of a population of 8.1 million. ${ }^{33}$ The situation changed after 2001 in Azerbaijan, because of massive oil exports: income started to rise again quickly and the flow of migrants reversed.

A last and specific argument frequently advanced in informal discussions, is that of military conflicts. All three countries have expressed the need to have more soldiers, therefore more boys, to defend their borders. Armenia and Azerbaijan fought for control of High Karabakh (1988-1994), while Georgia faced several conflicts with South Ossetia (1990-1992), with Abkhazia (1992-1993), and with Russia (2008). ${ }^{41,42}$

\section{Discussion}

This paper proposes a broad framework for analyzing the fast rise in sex-ratio at birth in Southern Caucasus in the 1990s and its stabilization in the 2000s. This framework differs from the vague "patriarchal framework". Indeed, most societies in Caucasus, Middle East, and Central Asia, and elsewhere as well, are typically "patriarchal" - patriarchal societies being defined by three main criteria: male authority in the household (male domination/female subordination); patrilineal descent (family name, kinship, and ethnicity being inherited from the father); and virilocal residence (wife moves to live in husband's residence). Despite similar social organization, only the Southern Caucasus societies practice SSA so far, and not other nearby societies with a similar social endowment.

Likewise, "preference for sons" seems to be comparable in nearby societies, and therefore cannot be retained as a serious argument for explaining SSA in the Caucasus. In a thorough analysis of indifference or preference for boys or girls, Fuse ${ }^{36}$ showed that preference for boys (or girls) in the three countries located in the Southern Caucasus did not differ from those in nearby countries where SSA did not occur. ${ }^{36,38}$ Note also that other cultural factors such as religion, or level of development could not explain SSA in Southern Caucasus. Two countries are predominantly Christian (Armenia and Georgia), the third is predominantly Muslim, and they differ in SSA behavior 
from nearby Christian countries (such as Russia or Ukraine) and from nearby Muslim countries (such as Turkey or Central Asian countries). The SSA behavior also seems largely independent from socioeconomic factors at the household level, such as income, poverty, level of education, or urbanization, and SSA is practiced in all strata of these societies.

A key factor for explaining SSA seems to be the local ethics, both from the medical establishment, whose active collaboration is necessary, and from the population. Beyond economic constraints, social values, marketing from pharmaceutical companies, and the development of private medical practice, the societies of Southern Caucasus appear to be particularly tolerant to both abortion and sex-selection. The state is also particularly tolerant or cautious, and so far does not take any firm positive or negative stand - SSA is seen primarily as a private matter. The fact that the sex-ratio increased very quickly and similarly in the three countries indicates that they had all the conditions to accept this new behavior once the technology became available. The fact that the situation stabilized after 10 years in a similar way indicates that saturation occurred quickly, and that the new behavior had rapidly reached the segment of the population susceptible to adopt it. Stabilization in sex-ratios seems also associated with a new increase in fertility and with some improvement in the economic situation after the year 2000.

Acceptability of SSA raises an endless ethical debate, as is the case for abortion in general (ie, pro-life/pro-choice arguments). To shed light on this debate, we refer to the basic principles of medical ethics, namely nonmaleficence, beneficence, autonomy, and justice. ${ }^{43}$ In the case of induced abortion in general, the conflict lies between the principle of "nonmaleficence", which is the rationale of the "pro-life" position, and the principle of "autonomy" which is the rationale of the "pro-choice" position. In the peculiar case of SSA, the ethical dilemma lies between the principle of "equity" or "justice" (no differential treatment of male and female fetuses) and the principle of "autonomy", or liberty of choice for family composition. The latter conflict is as impossible to resolve as the former, and this point is likely to induce endless debates in the future. As a consequence, societies may accept induced abortion for a variety of reasons, but may reject SSA if they give more value to sex equity.

In conclusion, the main rationale for explaining SSA in countries of Southern Caucasus seems to be a conjunction of several factors: a general availability and high acceptability of abortion and sex-determination techniques by both the medical establishment and the population, within a context of changing desired family size, low fertility, large migration flows, political instability with threat of wars, economic difficulties, and restructuring following the dismantlement of the Soviet Union. To these elements, one could add the marketing from pharmaceutical companies selling equipment for sex-determination and the attractive power of new opportunities for sex-selection following a wave of new political and economic liberties. The fact that sex-ratios tended to stabilize or slightly decline since 2001 , in a context of a more favorable economic situation and somewhat rising fertility, suggests that the rise in SSA in the 1990s might be more of a transient behavior, a new opportunity for birth control by South Caucasian families in a difficult context, rather than a long-term structural feature of the society.

These phenomenon are rather new in a broad historical perspective, and further research is needed on features of the decision-making process within couples (discussions, negotiations, and possible conflicts). The final decision might also induce conflicts or even violence within families, as is the case for induced abortion in general, but so far we have seen no example of such behavior in our interviews. More research is also needed on changing attitudes of the medical establishment and that of governments, who are under international pressure and under pressure from religious authorities. In this respect, one can note that Sweden recently adopted an open attitude towards SSA, the main argument being to not refuse abortion because of sex preferences, paving the way to a new approach to these issues. ${ }^{44}$ Note that Sweden has been for a long time a pioneer on induced abortion, and overall more tolerant than other Western countries.

\section{Acknowledgments}

SAH and CAL warmly thank all the persons who welcomed them in Armenia, Azerbaijan, and Georgia, and accepted long discussions on these difficult issues. The authors warmly thank Ms France Toma from IRD, Bondy, who taped and formatted the video abstract.

\section{Disclosure}

The authors report no conflicts of interest in this work.

\section{References}

1. Artamonova E. Praktika selecktivnyh abortov I gendernyi porâdokv Azerbaidjane. In: Razgadat Iujnij Kavkaz: Obshtshesva I sreda obitaniâ. [The practice of selective abortion and gender issues in Azerbaijan]. Tbilissi, Georgia: Heinrich Böll Stiftung; 2006:169-204. Russian.

2. Cai Y, Lavely W. Child sex ratios and their spatial variation. In: Zhao Z, Guo F, editors. Transition and Challenge. China's Population at the Beginning of the 21st Century. Oxford, UK: Oxford University Press; 2007:108-123.

3. Chu J. Prenatal sex determination and sex-selective abortion in rural central China. Popul Dev Rev. 2001;27(2):259-281. 
4. Chung W, Das Gupta M. The decline of son preference in South Korea. The roles of development and public policy. Popul Dev Rev. 2007;33(4): 757-783.

5. Das Gupta M, Bhat PN. Fertility decline and increased manifestation of sex bias in India. Popul Stud. 1997;51(3):307-315.

6. Das Gupta M, Zhenghua J, Bohua L, Zhenming X, Chung W, Hwa-Ok B. Why is son preference so persistent in East and South Asia? A cross-country study of China, India and the Republic of Korea. J Dev Stud. 2003;40(2):153-187.

7. Duthé G, Meslé F, Vallin J, Badurashvili I, Kuyumjyan K. High level of sex ratio at birth in the Caucasus. A persistent phenomenon? PAA Conference; March 31-April 2, 2011; Washington, DC.

8. Duthé G, Meslé F, Vallin J, Badurashvili I, Kuyumjyan K. High sex ratios at birth in the Caucasus. Modern technology to satisfy old desires. Popul Dev Rev. 2012;38(3):487-501.

9. Guilmoto CZ. The sex ratio transition in Asia. Popul Dev Rev. 2009;35(3):519-549.

10. Jha P, Kesler MA, Kumar R, et al. Trends in selective abortions of girls in India: analysis of nationally representative birth histories from 1990 to 2005 and census data from 1991 to 2011. Lancet. 2011;377(9781): 1921-1928.

11. Meslé F, Vallin J, Badurashvili I. A sharp increase in sex ratio at birth in the Caucasus. Why? How? In: Attané I, Guilmoto C, editors. Watering the Neighbour's Garden: the Growing Demographic Female Deficit in Asia. Paris, France: CICRED; 2007:73-88.

12. Pham BN, Hall W, Hill PS, Rao C. Analysis of socio-political and health practices influencing sex ratio at birth in Viet Nam. Reprod Health Matters. 2008;16(32):176-184.

13. United Nations Fund for Population Activities (UNFPA). Sex imbalances at birth: current trends, consequences and policy implications. United Nations: Bangkok, Thailand; 2012.

14. Zeng Y, Tu P, Gu B, Xu Y, Li B, Li Y. Causes and implications of the recent increase in the reported sex ratio at birth in China. Popul Dev Rev. 1993;19(2):283-302.

15. Greenhalgh S. Patriarchal demographics? China's sex ratio reconsidered. Popul Dev Rev. 1993;38(Suppl 1):130-149.

16. Van Balen F. Attitudes towards sex selection in the Western world. Prenat Diagn. 2006;26(7):614-618.

17. Williamson NE. Sons or Daughters: A Cross-Cultural Survey of Parental Preferences. Beverly Hills, CA: Sage Publications, Inc.; 1976.

18. Chakroborty T, Sukkoo K. Kinship institutions and sex ratios in India. Demography. 2010;47(4):989-1012.

19. Emerson DS, Felker RE, Brown DL. The sagittal sign. An early second trimester sonographic indicator of fetal gender. J Ultrasound Med. 1989;8(6):293-297.

20. Odeh M, Granin V, Kais M, Ophir E, Bornstein J. Sonographic fetal sex determination. Obstet Gynecol Surv. 2009;64(1):50-57.

21. Alfirevic Z, Sundberg K, Brigham S. Amniocentesis and chorionic villus sampling for prenatal diagnosis. Cochrane Database Syst Rev. 2003;(3):CD003252.

22. Devaney SA, Palomaki GE, Scott JA, Bianchi DW. Noninvasive fetal sex determination using cell-free fetal DNA: a systematic review and meta-analysis. JAMA. 2011;306(6):627-636.

23. Cheng L. Surgical versus medical methods for second-trimester induced abortion. The WHO Reproductive Health Library. Geneva, Switzerland: World Health Organization; 2008.

24. Kulier R, Kapp N, Gülmezoglu AM, Hofmeyr GJ, Cheng L, Campana A. Medical methods for first trimester abortion. Cochrane Database Syst Rev. 2011;(11):CD002855.

25. Fjerstad M, Sivin I, Lichtenberg ES, Trussell J, Cleland K, Cullins V. Effectiveness of medical abortion with mifepristone and buccal misoprostol through 59 gestational days. Contraception. 2009;80(3): $282-286$.
26. World Health Organization. Safe Abortion: Technical and Policy Guidance for Health Systems. 2nd ed. Geneva, Switzerland: World Health Organization; 2012:134.

27. World Health Organization. Clinical practice handbook for safe abortion. Geneva, Switzerland: World Health Organization; 2014:72.

28. Blum A. Naître, vivre et mourir en URSS (1917-1991). [To be born, live and die in the USSR (1917-1991)]. Paris, France: Plon; 1994:273. French.

29. Avdeev A, Blum A, Troitskaja I. Histoire de la statistique de l'avortement en Russie et en URSS jusqu'en 1991 [History of statistics on abortion in Russia and USSR until 1991]. Population. 1994;49(4-5):903-933. French.

30. Garenne M. Education and fertility in sub-Saharan Africa: a longitudinal perspective. DHS Analytical Studies No 33. Calverton, MD: ICF International; 2012:127.

31. Zajončkovskaâ ŽA. Demografičeskaâ situaciâ I rasselenie. [The demographic situation and population process]. Moscow, Russia: Nauka; 1991. Russian.

32. Zajončkovskaâ ŽA, editor. Trudovaya migrasiya v SNG: sotsialniye $i$ economicheskiye effecti. [Labor Migration in the CIS: Social and Economic Impacts]. Moscow, Russia: Institute for Economic Forecasting of the Russian Academy of Sciences; 2003. Russian.

33. Ivakhnyuk I. Migration in the CIS region: common problems and mutual benefits. International symposium on international migration and development, United Nations, Population Division; Jun 2006

34. Zurabishvili T, Zurabishvili T. The feminization of labor migration from Georgia: the case of Tianeti. Labaratorium. 2010;1:73-83.

35. Badurashvili I. Out-migration from Georgia to Moscow and other destinations. In: Genov N, Savvidis T, editors. Transboundary Migration in the Post-Soviet Space: Three Comparative Case Studies. Frankfurt am Main, Germany: Peter Lang; 2011:79-122.

36. Fuse K. Variations in attitudinal gender preferences for children across 50 less-developed countries. Demographic Res. 2010;23(36): 1031-1048.

37. The State Statistical Committee of the Republic of Azerbaijan. Women and Men in Azerbaijan [webpage on the Internet]. Baku, 2012. Available from: http://www.stat.gov.az/source/demoqraphy/indexen.php. Accessed October 15, 2013

38. Garenne M, Hohmann S. Gender saturation in Southern Caucasus: family composition and sex-selective abortion. J Biosoc Sci. Epub February 21, 2014.

39. Troitskaia I, Avdeev A, Badurashvili I, Kapanadze E, Tretjaküva V. Étude comparative des pratiques contraceptives: France, Géorgie, Lituanie et Russie [Comparative study of contraceptive practices : France, Georgia, Lithuania, and Russia]. Revue d'Etudes Comparatives Est-Ouest. 2009; 40: 241-272. French.

40. Westoff CF. Recent trends in abortion and contraception in 12 Countries. No 8. DHS Analytical Studies. Calverton, MD: ORC Macro; 2005.

41. Serrano S. Géorgie: Sortie d'empire. [Georgia: exiting from the Empire]. Paris, France: CNRS Editions; 2007:338. French.

42. Merlin A, Serrano S, editors. Ordres et désordres dans le Caucase [Orders and disorders in the Causasus]. Brussels, Belgium: Editions de l'Université de Bruxelles; 2010. French.

43. Beauchamp TL, Childress JF. Principles of Biomedical Ethics. 5 th ed. Oxford, UK: Oxford University Press; 2001.

44. Sandberg A. Biting into the sour apple: liberal society, abortion rights and sex selection [May 13, 2009]. Practical Ethics; Ethics in the News: University of Oxford. Available from: http://blog.practicalethics.ox.ac. uk/2009/05/biting-into-the-sour-apple-liberal-society-abortion-rightsand-sex-selection/. Accessed August 27, 2014. 
International Journal of Women's Health

Dovepress

\section{Publish your work in this journal}

The International Journal of Women's Health is an international, peerreviewed open-access journal publishing original research, reports, editorials, reviews and commentaries on all aspects of women's healthcare including gynecology, obstetrics, and breast cancer. The manuscript management system is completely online and includes Visit http://www.dovepress.com/testimonials.php to read real quotes from published authors.

Submit your manuscript here: http://www.dovepress.com/international-journal-of-womens-health-journal 